\title{
PERAN KEPEMIMPINAN KEPALA SEKOLAH DALAM MEMBINA KOMPETENSI SOSIAL (PELAYANAN PRIMA) TENAGA ADMINISTRASI SEKOLAH
}

\author{
${ }^{1}$ Tri Yuliani dan ${ }^{2}$ Muhammad Kristiawan \\ ${ }^{1}$ Pegawai IAIN Batusangkar \\ e-mail: ie_tiew@yahoo.com \\ ${ }^{2}$ Dosen Program Studi Magister Manajemen Pendidikan \\ Universitas PGRI Palembang \\ e-mail: muhammad.kristiawan@yahoo.co.id
}

\begin{abstract}
A good service gives more satisfaction to the customers. This study used qualitative approach to explore the stakeholders' competence in school in advising social competence (quality service). This research focused on administration staff that give quality service to the customers. The data were collected through observation and interview. The data analyisis of this research used Miles \& Huberman's model. The results revealed that administration staff needs training and educational program to improve the competence.
\end{abstract}

Keyword: Leadership, Headmaster, Training and Education, Administration Staff, Quality Service.

\section{PENDAHULUAN}

Penelitian ini berawal dari wacana awal bahwa "tenaga administrasi sekolah (tenaga kependidikan) hendaklah bersikap seperti pegawai swasta (pelayanan pegawai bank)" (Perkuliahan Kepemimpinan Pendidikan Islam di IAIN Batusangkar dengan Dr. M. Kristiawan, tanggal 9 April 2016). Penulis mengartikan bersikap seperti pegawai swasta di sini adalah dengan memberikan pelayanan prima kepada setiap costumer yang ada di sekolah. Kemampuan memberikan pelayanan prima tersebut harus dimiliki oleh tenaga administrasi sekolah. Hal ini sesuai dalam Permendiknas No. 24 tahun 2008 mengenai Standar Tenaga
Administrasi sekolah harus memiliki kemampuan atau kompetensi yaitu kompetensi kepribadian, kompetensi sosial, kompetensi teknis, dan kompetensi manajerial (khusus Kepala Tenaga Administrasi Sekolah).

Pelayanan prima di sini adalah salah satu bagian dari komptensi sosial yang harus dimiliki oleh tenaga administrasi sekolah di samping kompetensi-kompetensi lainnya. Kegiatan pelayanan ini identik dengan sikap dan perilaku dari tenaga administrasi sekolah dalam melaksanakan tugasnya. Tenaga administrasi sekolah memiliki tugas melayani secara prima membantu pelanggan dalam memenuhi kebutuhannya dan 
dilakukan dengan cara yang terbaik sehingga pelanggan merasa sangat puas (Kemendiknas, 2010). Pasolong (2007) mendefinisikan pelayanan sebagai aktivitas seseorang, sekelompok atau organisasi baik langsung maupun tidak langsung untuk memenuhi kebutuhan.

Pelayanan yang ditemukan di sekolah saat ini cenderung masih lamban, tidak tepat waktu, kurang ramah, kurang komunikatif, dan bahkan masih ada juga memakai bahasa yang tidak enak didengar. Fenomena senada juga dikemukakan dalam penelitian Rodiyah (2014) yang mengatakan bahwa ketika pengguna jasa membutuhkan pelayanan dengan cepat dari petugas namun petugas justru kurang tanggap dan birokrasi yang rumit dan tidak semuanya dimengerti oleh semua pengguna jasa. Umumnya pengguna jasa baru mengetahui syarat-syarat yang harus dipenuhi dan apa yang harus dilakukan setelah mendatangi instansi dan biasanya waktu penyelesaiannya tidak jelas tergantung pada pelayanan yang dituju, walaupun UPTD Dinas Pendidikan Kecamatan Porong telah membuat kebijakan waktu pelayanan prima sesuai dengan Standar Pelayanan Publik (SPP).

Fenomena lain yang terlihat di lapangan adalah kurangnya kemampuan atau kompetensi yang dimiliki petugas tenaga administrasi dalam melaksanakan tugasnya bisa dikatakan tergolong masih rendah terutama dalam bidang pelayanan prima kepada siswa, orang tua dan masyarakat yang tampak masih kurang ramah. Hal senada juga diungkapkan oleh (Joko, 2007) dalam (Baehaki, Zahro, 2013) bahwa "kompetensi tenaga administasi sekolah masih rendah, masih banyak tenaga admistrasi yang belum mempunyai kemampuan dan keterampilan yang memadai dalam melaksanakan tugasnya. Kinerja, disiplin, loyalitas dan tanggung jawab tenaga administrasi sekolah masih rendah. Pelayanan prima kepada siswa, orang tua dan masyarakat masih belum tampak".

Hal-hal seperti ini menjadi salah satu faktor yang menyebabkan setiap orang yang ingin berinteraksi dengan tanaga administrasi sekolah menjadi tidak puas dan memberikan kesan jengkel pada pelanggan. Pelayanan yang sering menunda-nunda kepentingan pelanggan juga sering kita temui pada sekolah-sekolah saat ini. Hal ini jauh sekali dari gambaran konsep pelayanan prima berdasarkan A5 yang dikemukakan oleh Barata (2004) yaitu pendekatan sikap (attitude), pendekatan perhatian (Attention), dan pendekatan tindakan (Attention). Untuk melaksankan konsep pelayanan prima tersebut juga tidak terlepas dari pembinaan kepala sekolah yang selalu memberikan perhatian kepada bawahannya. Kepala 
sekolah sebagai pemimpin berperan memberikan pembinaan tidak hanya kepada tugas guru dalam melaksanakan tugasnya tapi juga pembinaan kompetensi kepada tenaga administrasi sekolah (tenaga kependidikan) dalam melaksankan tugasnya. Menurut kartono (2006), kepemimpinan adalah bentuk dominasi yang didasari kemampuan pribadi, yang sanggup mendorong atau mengajak orang lain untuk berbuat suatu berdasarkan akseptasi/penerimaan oleh kelompoknya, dan memiliki kelahlian khusus yang tepat bagi situasi khusus.

Sementara itu Terry dalam (Kartono, 2006) mendefinisikan kepemimpinan adalah aktivitas mempengaruhi orang-orang untuk mencapai tujuan kelompok. Dalam usaha mencapai tujuan tersebut perlu seorang pemimpin untuk melakukan supervisi untuk menjaga apakah langkah- langkah yang diambil telah sesuai dengan peraturan yang telah ditetapkan. Di mana Terry mengungkapkan bahwa supervisi adalah usaha mencapai hasil yang diinginkan dengan cara mendayagunakan bakat atau kemampuan alami manusia dan sumbersumber yang memfasilitasi, yang ditekankan pada pemberian tantangan dan perhatian yang sebesar-besarnya terhadap bakat atau kemampuan alami manusia.
Dari definisi kepemimpinan tersebut di atas dapat diartikan bahwa kepemimpinan menyangkut sebuah proses pengaruh sosial yang dalam hal ini pengaruh yang disengaja dijalankan oleh seseorang terhadap orang lain untuk menstruktur aktivitas serta hubunganhubungan di dalam sebuah kelompok atau organisasi. Pemimpin memiliki pengaruh dan memberikan pembinaan kepada tenaga administrasi sekolah. Dari data tersebut, dapat ditarik permasalahan yang dihadapi pada penelitian ini yaitu bagaimana peran Kepala Sekolah dalam membina kemampuan sosial (pelayanan prima) Tenaga Administrasi Sekolah.

\section{METODE PENELITIAN}

Penelitian ini menggunakan pendekatan kualitatif studi kasus (case study). Case Study didefinisikan sebagai suatu metode untuk memahami individu yang dilakukan secara integratif dan komprehensif agar diperoleh pemahaman yang mendalam tentang individu tersebut beserta masalah yang dihadapinya dengan tujuan masalahnya dapat terselesaikan dan memperoleh perkembangan diri yang baik (Raharjo \& Gudnanto, 2011). Case Study menyiratkan peneliti melakukan analisis secara intensif pada satu unit analisis yang diteliti (Case). Case Study dalam hal ini bertujuan untuk mengetahui peran kepemimpinan kepala 
sekolah dalam membina kompetensi sosial (pelayanan prima) tenaga administrasi sekolah. Pengambilan data dilakukan dengan kepala sekolah dan beberapa tenaga administrasi sekolah dalam melaksanakan tugasnya saat memberikan pelayanan.

Instrumen penelitian yang digunakan wawancara dan observasi. Menurut Djamaan dan Aan (2011) wawancara merupakan "teknik pengumpulan data yang sering digunakan dalam penelitian kualitatif". Melaksanakan teknik wawancara berarti melakukan interaksi komunikasi atau percakapan antara pewawancara (interviewer) dan terwawancara (interviewee) dengan maksud menghimpun informasi dari interviewee. Interviewee pada penelitian kualitatif adalah informan yang daripadanya pengetahuan dan pemahaman diperoleh. Metode observasi didefinisikan sebagai pengamatan akan manusia pada "habitatnya" (Sarosa, 2012). Observasi bertujuan untuk melihat keadaan pelayanan yang diberikan oleh tenaga administrasi sekolah yang sedang berjalan.

Berdasarkan dari teori di atas, informan dalam penelitian ini adalah tenaga administrasi sekolah. Peneliti memilih sendiri informan dalam wawancara ini dengan cara purposive sampling. Purposive sampling adalah salah satu jenis pengambilan sampel dalam penelitian kualitatif. Menurut Gay
(2000) purposive sampling berarti peneliti memilih sampel berdasarkan pengalamannya atau pengetahuan dari kelompok untuk menjadi sampel. Ukuran sampel purposive sampling yang diperlukan sangat bergantung pada sumber, waktu yang tersedia, dan tujuan penelitian (Arifin, 2011).

Teknik pengambilan data pada penelitian ini dengan menggunakan metode observasi dan wawancara. Peneliti menggunakan telepon genggam dan tape recorder untuk mendapatkan reaksi atau jawaban dari pertanyaan yang diberikan peneliti kepada informan dan sekaligus menjadi bahan atau alat pendukung dalam melakukan penelitian ini. Analisis data yang digunakan dalam penelitian ini adalah Miles \& Huberman (1994) yaitu (1) reduksi data; (2) penyajian data; dan (3) penarikan kesimpulan/verifikasi (Emzir, 2011).

\section{HASIL PENELITIAN DAN PEMBAHASAN}

Pada bagian ini menggambarkan hasil tentang peran kepemimpinan kepala sekolah dalam membina kompetensi sosial (pelayanan prima) tenaga administrasi sekolah. Pengambilan data dilakukan dengan melakukan wawancara kepada beberapa orang informan yang berprofesi sebagai tenaga administrasi sekolah yang melakukan pelayanan kepada pelanggan. Wawancara dilakukan mulai hari minggu 6 Maret 2016. 
Pada saat melakukan wawancara, peneliti menggunakan wawancara tidak terstruktrur dan bebas, namun memiliki poin penting yang akan ditanyakan.

Berdasarkan dari deskripsi data, maka ada beberapa komponen dari Peran Kepemimpinan Kepala Sekolah dalam membina kompetensi sosial (pelayanan prima) Tenaga Administrasi Sekolah dan kepemimpinan kepala sekolah berhubungan dengan bagaimana strategi pembinaan yang dilakukan oleh kepala sekolah kepada tenaga administrasi dalam melaksanakan tugas tersebut. Disi lain juga dilihat pelaksanaan dari kemampuan sosial (pelayanan prima) yang dimiliki oleh tenaga administrasi sekolah tersebut.

Sebelum dilakukan pembinaan oleh kepala sekolah maka dilihat dulu dari komponen kemampuan sosial (pelayanan prima) yang dimiliki oleh tenaga administrasi sekolah berdasarkan indikator kualitas pelayanan prima yang baik meliputi: (1) memberikan kemudahan; (2) menetapkan layanan sesuai standar; (3) berempati kepada pelanggan; (4) berpenampilan prima; (5) menempati janji; (6) bersikap ramah dan sopan; (7) mudah dihubungi; (8) komunikatif (Permendiknas, No. 24 Tahun 2008)

Pelayanan pertama dari tenaga adminstrasi sekolah adalah memberikan kemudahan kepada pelanggan dan mudah dihubungi. Memberikan kemudahan sekaligus memberikan arti jika tenaga administrasi sekolah mudah dihubungi. Mereka (informan) mengatakan bahwa kemampuan yang mereka miliki dalam pelayanan memberikan kemudahan adalah dengan sikap yang tanggap atau sigap. Hal ini dapat dilihat dari jawaban informan 1 (Adi) tentang bagaimana cara anda memberikan pelayanan kepada pelanggan yang memberikan kemudahan ini? Beliau menyatakan "dia tidak membedakan siapa yang membutuhkan pelayanan tersebut, setiap orang yang baru datang tidak dilihat latar belakangnya dan langsung menghampiri atau menyapa pelanggan dan menyuruhnya langsung masuk". Ia juga tidak segan memberikan nomor kontak yang bisa dihubungi jika terjadi kendala atau satu hal yang belum bisa dimengerti saat pertemuan berlangsung.

Kemudian untuk melihat keyakinan atau kejujuran informan dalam menjawab, peneliti memberikan pertanyaan kedua yang berhubungan dengan kualitas pelayanan prima yang menetapkan layanan sesuai dengan standar dan berempati kepada masyarakat yang datang yaitu apakah yang anda lakukan sesuai dengan sistem pelayanan tenaga administrasi yang benar? Menurut informan 1 (Adi) "ia benar sesuai dengan standar yang telah diatur dalam permen 
tersebut". Di sisi lain pertanyaan yang sama diajukan kepada informan 2 (Ari) "ia melayani setiap yang datang sesuai dengan etika sopan santun dan ramah seperti sikap baik kepada semua orang".

Peneliti mengartikan hasil wawancara pada informan pertama, ia telah menyadari permen yang mengatur sikap kerja, sehingga ia dapat bekerja sesuai dengan aturan yang berlaku. Namun pada informan kedua, ia kurang mengetahui adanya permen yang mengatur tentang tata cara memberikan pelayanan prima tetapi ia tetap melaksanakan dengan sebaik mungkin dan memberikan sikap yang tidak menyinggung orang lain.

Kemudian pada pertanyaan tentang bagaimana sistem pelayanan administrasi? Informan 2 menjawab "belum ada aturan yang mengikat dari tugasnya sebagai tenaga administrasi sekolah ini. Namun dari informan 3 (Amri) menyatakan bahwa dengan sistem yang ada memberikan kemudahan kepadanya dalam menjalankan tugas karena ada SOP (Standar Operasional Pekerjaannya).

Dari beberapa jawaban di atas memperlihatkan bahwa dari 3 informan yang menjadi objek wawancara, peneliti menyimpulkan bahwa tenaga administrasi telah memenuhi aspek 1 dan 2 dalam pelayanan prima yaitu memberikan kemudahan kepada pelanggan dan melaksanakan sesuai dengan standar. Hal ini dikarenakan mereka menjalankan tugas pelayanan yang memberikan kemudahan kepada pelanggan dan mengerjakannya sesuai dengan standar kerja tenaga administasi dan sistem yang ada yang dilihat dari hasil jawaban aspek 2. Hal ini sesuai dengan pendapat Barata (2003) yang menyatakan layanan istimewa "Service Excellent" didefenisikan sebagai kepedulian kepada pelanggan dengan memberikan layanan terbaik untuk memfasilitasi kemudahan pemenuhan kebutuhan dan mewujudkan kepuasan, agar mereka selalu loyal kepada organisasi.

Sesuai dengan penelitian Abdussamad (2000) yang menyatakan perlunya standar pelayanan yang jelas meliputi prosedur, jangka waktu, dan kalau perlu biaya yang jelas guna mendorong terciptanya lembaga pelayanan yang teratur dengan membangun sistem standarisasi pelayanan mulai dari input, sampai dengan output pelayanan. Instalasi pelayanan harus mempunyai standar pelayanan yang dipergunakan sebagai tolok ukur/pedoman dalam hal penyelenggaraan pelayanan.

Hal ini sesuai dengan hasil penelitian Rodiyah \& Kholipatun (2014) pegawai mengerjakan tugasnya dengan penuh kehandalan (reliability), yakni kemampuan memberikan jasa dengan akurat dan 
profesional. Menurut hasil wawancara dan pengamatan peneliti, kehandalan petugas pelayanan pembuatan izin pendirian lembaga baru, pembuatan rekomendasi, pengajuan NISN/NPSN, pembuatan surat keterangan, legalisir ijasah dan lain-lain, ternyata belum dijumpai keluhan mengenai ketelitian petugas dalam melayani pengguna jasa. Hal ini sesuai dengan penuturan As selaku pimpinan "Kepala UPTD Cabang Dinas Pendidikan Kecamatan Porong menjamin bahwa petugas dalam menjalankan tugasnya dilakukan secara teliti dan saksama sebagaimana tenaga yang terlatih, sehingga terjamin keandalan para petugas pada bagian pelayanan" (Hasil wawancara, 15 Mei 2014). Ini menunjukkan bahwa tenaga administrasi dalam melaksanakan tugas dengan penuh keandalan agar dapat memberikan pelayanan yang beriorientasi pada pemberian kemudahan kepada pelanggan karena bekerja sesuai dengan standar dengan penuh ketelitian dan terlatih.

Pertanyaan selanjutnya untuk melihat rasa empati, ramah dan sopan pada tenaga administrasi dalam melaksanakan tugas, peneliti memberikan pertanyaan apakah anda melayani setiap orang yang datang berurusan tanpa melihat asal usul ataupun latar belakangnya? Informan 3 (Amri) menyatakan "saya berusaha terbuka dan melayani dengan slogan $3 \mathrm{~S}$ dalam bekerja itu adalah senyum, sapa, salam". Sedangkan informan 2 (ari) menyatakan "saya malas melayani orang tua wali murid yang berurusan ke sekolah masih menggunakan baju tidur"

Dapat disimpulkan bahwa tenaga administrasi belum dapat sepenuhnya memenuhi kriteria 3 dan 6 yaitu bersikap empati, ramah dan sopan. terbukti adanya rasa empati, ramah dan sopan dari tenaga administrasi dalam melaksanakan tugas memberikan pelayanan prima. Namun di sisi lain meskipun malas melayani orang tua yang sedikit kurang etika namun ia masih melayani dengan rasa empati. Menurut Zoll dan Enz (2012) empati dapat diartikan sebagai kemampuan dan kecenderungan seseorang (observer) untuk memahami apa yang orang lain (target) pikirkan dan rasakan pada situasi tertentu. Wawancara ini memperlihatkan rasa empati yang diberikan pada saat melakukan pelayanan sudah terlihat dengan baik. Berkaitan dengan simpati merupakan cara untuk mengungkapkan rasa iba atau prihatin terhadap suatu musibah atau peristiwa buruk yang menimpa orang lain.

Empati merupakan salah satu bentuk emosi kesadaran diri, selain rasa malu, rasa cemburu, rasa bangga dan rasa bersalah. Menurut Darwin, emosi-emosi tersebut berawal dari perkembangan kesadaran diri dan melibatkan penguasaan peraturan dan 
standar (LaFreniere, 2000). Senada dengan hasil penelitian Rodiyah \& Kholipatun (2014), perhatian (emphaty) yakni memberikan perhatian kepada konsumen secara personal dan istimewa serta selalu berusaha memahami keluhan dan keinginan mereka. Pelayanan di UPTD Cabang Dinas Pendidikan Kecamatan Porong dalam hal pembuatan perizinan dan rekomendasi telah ditangani dengan sebaik mungkin.

Pada pertanyaan berikutnya mengenai berpenampilan prima, menempati janji, mudah dihubungi dan komunikatif, peneliti memberikan pertanyaan bagaimana komitmen kerja, penampilan dan bahasa yang bapak gunakan saat memberikan pelayanan? Informan 1 (Adi) menyatakan bahwa "saya bekerja dengan komitmen yang telah melekat seperti aturan berpakaian dari dinas yang terkait, dan bahasa yang mudah dimengerti oleh orang yang datang berurusan". Meyakinkan jawaban dari informan 1 peneliti mengajukan pertanyaan yang sama pada informan 2 (Ari) ia menyatakan "saya berusaha memberikan contoh berpenampilan dan bahasa yang bagus mudah dimengerti seperti bahasa Indonesia lah kepada murid atau siswa yang datang, supayo lamak mangecek dan tau orang tu apo maksud awak kalo manjalehan ka urang tuo murid".
Dari jawaban tersebut, peneliti dapat menyimpulkan bahwa tenaga administrasi telah memenuhi kriteria permen pada aspek 4, 5, 7, dan 8 yang mengatur tentang berpenampilan prima, menempati janji, mudah dihubungi dan komunikatif seperti memiliki komitmen dalam bekerja seperti yang dikatakan informan 1 dan didukung oleh jawaban informan 2 yang menyatakan ia berusaha komunikatif dan menggunakan bahasa yang mudah dimengerti. Senada dengan hasil penelitian Rodiyah \& Kholipatun (2014) Wujud fisik (tangibility), yakni menampilkan kemampuan sarana dan prasarana yang bersifat fisik. Pada kenyataannya di UPTD Cabang Dinas Pendidikan Kecamatan Porong tidak ada petugas yang tidak menggunakan seragam yang telah ditetapkan. Hal ini telah menunjukkan secara keseluruhan bahwa petugas telah bersikap disiplin dan ditunutut untuk berpenampilan rapi ketika memberikan pelayanan. Selain itu kebersihan toilet masih perlu diperhatikan, karena terdapat dinding toilet yang sudah rapuh. Fakta di atas, menunjukkan terdapat faktor yang sudah sesuai dan tidak sesuai dengan teori yang telah dikemukakan oleh Lovelock, sehingga perlu diadakan pembenahan lebih lanjut. Hal tersebut dibenarkan Su, Kasubag Tata Usaha bahwa "pihak pimpinan tidak henti-hentinya menginstruksikan kepada bawahan tentang 
perlunya tampil rapi dan enerjik serta petugas kebersihan selalu diperingatkan untuk merawat/memelihara kebersihan gedung dan sarana prasarananya misalnya untuk konstruksi gedung, perlengkapan kantor bahkan sampai toilet" (Hasil Wawancara, 15 Mei 2014).

Dari berbagai pernyataan yang diungkapkan informan tidak terlepas juga dari peran pemimpin dalam membina dan mengupayakan agar pelayanan tenaga administrasi yang dimiliki oleh instansi yang ia pimpin menjadi lebih baik dan optimal sesuai dengan peraturan atau permen yang berlaku. Di sisi lain, peneliti juga menanyakan kepada pimpinan sekolah terkait bagaimana peran kepala sekolah dalam melakukan pembinaan kepada tenaga administrasi?

Informan 4 (Joni) menyatakan "saya memiliki buku kontrol kerja yang saya tulis sebagai pedoman dan pantauan terhadap kerja dan kinerja setiap tenaga administrasi yang ada di sekolah. Buku ini saya isi untuk melihat tindakan apa yang akan saya lakukan, selanjutnya kepada tenaga administrasi yang saya miliki jika kurang apakah dengan memberikan pelatihan atau pembinaan kepadanya". Saat saya konfirmasi kepada salah satu informan 3 (Amri) ia menyatakan "Kepala Sekolah saya yang dulu ada memberikan perhatian kepada saya sehingga saya disuruh mengikuti pelatihan atau diklat untuk menambah wawasan saya".

Hal ini memberikan data kepada peneliti bahwasanya adanya perhatian dari Kepala Sekolah selaku pimpinan dalam melaksanakan tugas dengan memberikan pelatihan kepada tenaga administrasi yang dimilikinya. Perhatian yang diberikan Kepala Sekolah dapat dilihat dengan memberikan fasilitas sarana dan prasana yang dapat menunjang kerja optimal dari tenaga administrasi.

Sejalan dengan penelitian (Rinala, Yudana, dan Natajaya, 2013) yang menyatakan untuk optimalisasi kegiatan pelayanan diperlukan dimensi assurance (pengetahuan dan kemampuan untuk memberikan jaminan dan kepercayaan) juga menunjukkan pengaruh yang signifikan terhadap kepuasan mahasiswa. Hal ini mendukung hasil penelitian dari Arief dan Suryadinata (2010) yang menyatakan jaminan merupakan dimensi kualitas pelayanan yang kurang signifikan dalam mengukur kepuasan pelanggan atas pelayanan di universitas Trunojoyo. Penelitian lain Aryani dan Rosita (2010), Skogland and Siguaw (2004), menyatakan assurance merupakan faktor kualitas pelayanan pada bidang jasa pendidikan (Rinala, Yudana, dan Natajaya, 2013). Pihak Program Studi Pendidikan Guru Sekolah 
Dasar Universitas Ahmad Dahlan

Yogyakarta perlu memperbaiki peralatan dan perlengkapan layanan, peningkatan kondisi penampilan fisik ruangan pelayanan administrasi akademik, penampilan dosen dan karyawan yang rapi, memberikan pelatihan soft skill agar dosen dan karyawan dapat memberikan pelayanan yang lebih baik, selalu siap dalam membantu mahasiswa, bersikap ramah dan sopan dalam memberikan pelayanan akademik, serta mampu berkomunikasi baik dengan mahasiswa.

\section{KESIMPULAN}

Kesimpulan dalam penelitian ini adalah tenaga administrasi sekolah pada umumnya telah melaksanakan tugas sesuai dengan standar yang mengatur pelaksanaan tugas mereka dalam Permen no 24 tahun 2008. Dapat dikatakan sebagian besar tenaga administrasi melaksanakan poin dengan sebaik mungkin dan Kepala Sekolah memiliki peranan penting dalam membina tenaga administrasi dengan cara memberikan perhatian, bimbingan dan pelatihan dalam rangka meningkatkan wawasan tenaga admnistrasi tersebut.

\section{DAFTAR PUSTAKA}

Arifin, Zainal. (2011). Penelitian Pendidikan: Metode dan Paradigma Baru. Bandung: PT. Remaja Rosdakarya.
Abdussamad, Yuriko. (2000). Sistem Pelayanan Administrasi: Fakultas Ekonomi dan Bisnis.

Djama'an, Satori \& Aan, Komariah. 2011. Metodologi Penelitian Kualitatif Bandung: Alfabeta.

Emzir. (2011). Metodologi Penelitian Pendidikan Kuantitatif \& Kualitatif. Jakarta: PT RajaGrafindo Persada.

Gay, L. R. and Peter Airaisan. (2000). Educational Research. Competencies and for Analysis and Application. New Jersey: Prentice Hall. Inc.

Kartini, Kartono. (2006). Pemimpin dan Kepemimpinan. Jakarta: PT. Raja Grafindo Persada.

Kemendiknas. (2010). Tugas Tenaga Administrasi Sekolah. Jakarta: Kemendiknas.

LaFreniere. (2000). Emotional Development (A Biosocial Perspective): USA. Wadsworth.

Pasolong, Harbani. (2007). Teori Administrasi Publik. Alfabeta: Bandung.

Permendiknas No. 24 Tahun 2008

Rahardjo, Susilo \& Gudnanto. (2011). Pembahasan Individu Teknik Non Tes. Kudus: Nora Media Enterprise.

Rinala, I Nyoman. Yudana, I Made. dan Natajaya, I Nyoman. (2013). "Pengaruh Kualitas Pelayanan Akademik terhadap Kepuasan dan Loyalitas Mahasiswa Pada Sekolah Tinggi Pariwisata Nusa Dua Bali”. eJournal Program Pascasarjana 
Universitas Pendidikan Ganesha Program Studi Administrasi Pendidikan, Volume 4 Tahun 2013.

Sarosa, Samiaji. (2012). Dasar-Dasar Penelitian Kualitatif. Jakarta: PT. Index.

Surya, Priadi. (2012). Peran Penting Tenaga Administrasi Sekolah dalam Penguatan Budaya Sekolah Untuk Implementasi Pendidikan Karakter. Yogyakarta: Universitas Negeri Yogyakarta.
Zoll dan Enz. (2012). "Efektivitas Cognitive Behavior Therapy Dan Rational Emotive Behavior Therapy terhadap Gejala Dan Kemampuan Mengontrol Emosi Pada Klien Perilaku Kekerasan". Jurnal Penelitian. Keilmuan Keperawatan Jiwa Fakultas Ilmu Keperawatan Universitas Indonesia, Kampus UI Depok, Jakarta 10430, Indonesia. 